\title{
Gender and Violence against Political Candidates: Lessons from Sri Lanka
}

Elin Bjarnegård (D)

\author{
Uppsala University
}

Sandra Håkansson

Uppsala University

Pär Zetterberg

Uppsala University

A nascent body of literature has highlighted the violence (broadly defined) that women sometimes face as they enter politics. Some interpretations depict this violence as primarily gender motivated: women politicians are targeted because they are women. Another interpretation is that violence in some contexts is an everyday political practice

This article is based on work supported by the Swedish Research Council (grant no. 2015-03488). The authors wish to thank the International Foundation for Electoral Systems (IFES) and its Sri Lanka team for fantastic collaboration while conducting this study. They are also grateful to the Federation of Sri Lankan Local Government Authorities (FSLGA) for its support during the field research. Very helpful comments and suggestions were made by participants at the 2019 European Consortium for Political Research (ECPR) Joint Sessions, the 2019 European Conference on Politics and Gender (ECPG), the development studies research seminar at Uppsala University, and the gender and politics seminar at Uppsala University (UPPGAP), as well as the coeditor of Politics \& Gender and three anonymous reviewers. The authors are equal contributors to this article; names are listed in alphabetical order.

(C) The Author(s), 2020. Published by Cambridge University Press on behalf of The Women and Politics Research Section of the American Political Science Association. This is an Open Access article, distributed under the terms of the Creative Commons Attribution licence (http://creativecommons.org/licenses/by/4.0/), which permits unrestricted re-use, distribution, and reproduction in any medium, provided the original work is properly cited. doi:10.1017/S1743923X20000471

$1743-923 X$ 
targeting men and women alike. However, because we lack large-scale, systematic comparisons of men's and women's exposure to election violence, we know little about the extent to which - and how - candidate sex shapes this form of violence. We address this research gap by using original survey data on 197 men and women political candidates in the 2018 Sri Lankan local elections. Sri Lanka is a suitable case for analysis because it is a postconflict country in which political violence has been endemic and the number of women candidates has increased rapidly due to gender quota adoption. Overall, we find large similarities in men's and women's exposure to violence, suggesting that violence sometimes is part of a larger political practice. However, we find that women are exposed to forms of intimidation of a sexual nature more often than men. This finding demonstrates the need for gender-sensitive analyses of election violence.

Keywords: Gender, violence, elections, candidates, election violence, violence against women in politics, VAWIP, Sri Lanka

omparative politics research has long highlighted the myriad hurdles - structural and discriminatory - that women face when they seek to enter the male-dominated political arena. Women aspirants often do not have the same access to campaign finance (Muriaas, Wang, and Murray 2019) and political networks (Bjarnegård 2013) that their men colleagues do. Political parties are less likely to nominate women as candidates, and when they do, they are more likely to put them in nonelectable slots on the party list (Norris and Lovenduski 1995). Even when electoral gender quotas are in place, parties often find ways to circumvent them (Kenny 2013) or limit their influence to protect men incumbents (Bjarnegård and Zetterberg 2016). Women's campaigns receive less prominent media coverage than men's campaigns (Kahn 1996), and the attention that women candidates do get tends to focus more on their appearance and personal lives compared to men's (Kittilson and Fridkin 2008). Evidence of these gendered hurdles has been generated by the gender and politics research field's long-standing focus on comparing men and women in electoral politics.

More recently, research has also started to highlight the violence that some women face as they enter politics. Acts of violence constitute a different dimension of gender-related political obstacles compared to structural inequalities or discriminatory patterns and practices (see Bardall, Bjarnegård, and Piscopo 2019). As opposed to the foregoing hurdles, violent acts are often illegal and always illegitimate, and they intentionally seek to affect politics by violating the personal integrity of the target. Violence in the context of an election campaign, targeting political actors such as candidates, also violates electoral integrity (Bjarnegård 2018). While it is well established that women are targets of 
election violence as political candidates (ACOBOL 2012; Ballington 2018; Bardall 2011; Cerva Cerna 2014; Krook and Restrepo Sanín 2016a), it is still unclear to what extent and how candidate sex shapes experiences of violence. Analyses of violence against women in politics have, to the best of our knowledge, not explicitly and systematically compared the election violence faced by women and men (see Bjarnegård 2018). ${ }^{1}$

Some interpretations depict election violence targeting women as gender motivated, primarily affecting women politicians because they are women. Such interpretations commonly understand acts of violence against women as the embodiment of a backlash against women's increased political participation (see, e.g., Biroli 2016; Krook and Restrepo Sanín 2016a, 126). ${ }^{2}$ This perspective implies that interventions should be designed to tackle specific gender-based forms of election violence. Another interpretation is that violent attacks on women candidates can also be understood as unfortunate side effects of the increase of women in politics, including in contentious elections and violent contexts. This perspective suggests that women politicians may be targeted because they are politicians, rather than because they are women (see, e.g., Piscopo 2016) and that the phenomenon is part of a larger problem of election violence and needs to be tackled as such.

These two interpretations are not mutually exclusive, but they should be seen as different points of departure that generate different observable implications. The two interpretations - because they are women and because they are politicians - are also reflected in different perspectives on election violence in general. Election violence can be seen as an inherently strategic targeting of certain political actors (Bekoe 2012), but it can also be analyzed as a political and social practice, underpinned by militarized norms (e.g., Rasmussen 2018). If, in a given context, violence against women candidates is to be largely interpreted as a strategic targeting of women to protest and prevent their increased political presence, the observable implication should be that women are targeted

1. One exception is Bjarnegård's comparison of men and women candidates in the Maldives (forthcoming). Another exception is a study by Collignon and Rüdig (2020) on men and women political candidates' exposure to psychological violence in the United Kingdom. However, the main focus of their study is not on gender. Other new research compares the experiences of men and women elected officeholders (see, e.g., Håkansson, forthcoming; Herrick et al. 2019).

2. Although recent contributions acknowledge that not all violence faced by women in politics is gender motivated (Krook 2020; Krook and Restrepo Sanín 2020), the need for such a distinction was not articulated in early influential scholarship (Krook 2016, 2017, 2018; Krook and Restrepo Sanín 2016a, 2016b). 
to a greater extent than men. If, on the other hand, electoral violence is, above all, to be understood as a widespread everyday political and social practice, the observable implication should be that women are no more exposed to election violence than men candidates.

To explicitly address the distinct observable implications generated by these different interpretations, this article represents one of the first large- $N$ empirical analyses of men and women political candidates' exposure to different forms of election violence (physical, psychological, and sexual). More specifically, the aim of the analysis is to examine to what extent and how candidate sex matters for the likelihood of being exposed to election violence in Sri Lankan local elections. Sri Lanka has two features that make the country a suitable case for analysis: first, it is a postconflict country in which political violence is still widespread and used by multiple political actors (e.g., Höglund and Piyarathne 2009; Uyangoda 2008); and second, the number of women candidates has increased rapidly due to the adoption of an electoral gender quota. To conduct the analysis, we make use of original survey data on 197 men and women political candidates in the 2018 local elections. In addition, we interviewed 21 men and women candidates.

To preview the findings, our survey data show fairly large similarities in the extent of election violence targeting women and men candidates, across most forms of violence. Other candidates and their supporters are believed to be behind the vast majority of attacks, indicating that election violence should first and foremost be understood as a problem that is part of general electoral practices in Sri Lanka, thus affecting women and men candidates alike. Nevertheless, we do find an important sex difference: women experience more sexualized psychological and physical violence than men do. The interview data add nuance to the survey findings, demonstrating that although both men and women experience psychological violence such as degrading talk, the content of the talk differs. While the men interviewed offer descriptions of how they are verbally attacked on political issues (such as accusations of corruption), women commonly describe attacks on their person (often sexually immoral behavior). This suggests that women may face other kinds of hurdles than men as candidates, even in a context in which both women and men are at a significant risk of being targeted with violence, potentially dampening Sri Lanka's first significant effort to increase women's representation. 


\section{GENDER AND VIOLENCE AGAINST POLITICAL CANDIDATES}

Elections are supposed to constitute the peaceful solution to political conflict, but far from all elections are peaceful. Election violence poses a threat not just to the personal integrity of victims but also to electoral integrity (Norris 2013). It consists of illegitimate attempts to exclude certain political actors from a fair political competition, and thus it has the potential to reinforce existing patterns of dominance and exclusion in politics. Election violence is a broad concept that is used to refer to different phenomena, perpetrated by different actors, with different motives, and against different targets (Staniland 2014). Common denominators among the various definitions are that it is carried out during an election period and with the intention of influencing the electoral process (Fischer 2002; Höglund 2009a). Fischer (2002, 3) defines election violence as "any random or organized act or threat to intimidate, physically harm, blackmail, or abuse a political stakeholder in seeking to determine, delay, or to otherwise influence an electoral process."

Even with this definition at hand, election violence can be conceptualized and viewed through different theoretical lenses and understood in various ways. Understanding election violence as primarily strategic implies that violence is used to reduce the competition in the electoral race, to influence the outcome of the election or to demonstrate outrage at election results (Bekoe 2012). Election violence can also be conceptualized as a political and social practice: an accepted and expected (though not legitimate) form of electoral conduct, underpinned by normalized and institutionalized violent norms and practices. Terminology such as "everyday" electoral violence has been used to differentiate strategic violent incidents from violence that is better understood as part and parcel of a broader political practice (e.g., Söderberg Kovacs 2018, 2).

How to characterize, understand, and interpret the violence that targets women politicians is an important challenge for research on gender and election violence, relating to a broader discussion in the emerging literature on gender and violence against politicians. Hitherto, many studies have taken as their point of departure the rapid increase in the number of women legislators across the globe (Albaine 2015; Cerva Cerna 2014; Krook 2015, 2017; Krook and Restrepo Sanín 2016a, 2016b), which is to a large extent the result of the expansion of electoral 
gender quotas (Hughes, Paxton, and Krook 2017). As larger numbers of women have acceded to political office during the last decades, there has been an increase in the number of testimonies and reports from women who have experienced violence or intimidation when pursuing their political work as candidates or representatives (ACOBOL 2012; Krook 2018; Krook and Restrepo Sanín 2020). As a result, violence against women in politics has often been interpreted as a backlash: a reaction to quotas or to women's increased involvement in electoral politics more broadly (Biroli 2016; Krook 2015, 2016; NDI 2018). It has been launched as a concept, with its own abbreviation and specific meaning: "violence against women in politics" (VAWIP). It is seen as a subset of gender-based violence, specifically denoting violence that is aimed at women because they are women, with the aim of preserving traditional gender roles in politics (Krook 2017; Krook and Restrepo Sanín 2016a).

While the manifestations of VAWIP have been carefully conceptualized in the literature (e.g., Krook 2015, 2017; Krook and Restrepo Sanín 2016a 2016b), successfully advocated by a number of organizations, ${ }^{3}$ and frequently referred to with Twitter hashtags (\#notthecost, \#vawip), less effort has been put into establishing its boundaries - that is, distinguishing VAWIP from violence that women may face because they are politicians (see, however, theoretical discussions by Bardall 2017; Bardall, Bjarnegård, and Piscopo 2019; Krook and Restrepo Sanín 2020).

The insight that electoral violence can be understood as part of a political practice, targeting women because they are politicians, may also affect the interpretation of violence that women experience in politics. For instance, interpreting the development in Latin America, Piscopo (2016) argues that what we see may not necessarily be interpreted solely as a backlash against women in politics, but also as increased attention to women politicians' experiences of a normalization - or routinization - of political violence. Piscopo $(2016,441)$ suggests that in some contexts, intimidation is "inscribed within the social fabric": politicians use violence as a means to negotiate power struggles. According to such a perspective, we should leave open the possibility that women politicians may be neither more nor less vulnerable to violence than men and that an increased number of women participating in politics in already violent contexts has increased the violence targeting women as politicians rather than as women.

3. For example, UN Women, the National Democratic Institute (NDI), the International Foundation for Electoral Systems (IFES), Peace Women, the South Asia Partnership, and the Inter-Parliamentary Union (IPU). 


\section{FORMS OF ELECTION VIOLENCE}

Definitions of election violence often include both physical and nonphysical forms of violence, including harassment, assault, intimidation, abuse, and destruction of property (e.g., Fischer 2002; Höglund 2009a). Hence, it is important to capture psychological forms of election violence as they correspond to the general scholarly understanding of the concept of election violence, and because they may be of particular importance in the study of potential sex differences. In this article, we therefore use a more comprehensive definition of violence, including not just physical forms but drawing on frameworks that also conceptualize psychological forms of political violence (Bardall 2011; Krook 2017; Krook and Restrepo Sanín 2016a).

Feminist research has long emphasized a continuum of violence, based on studies of normalization, escalation, and harm primarily in the home (Kelly 1988). Here, we recognize this continuum by conceptualizing forms of violence as belonging to one of two overarching categories: physical and psychological forms of violence (see also Bjarnegård forthcoming). Within these two overarching forms, violence still comes in many different shapes and can be carried out in various ways. Violence is defined as physical or psychological based on the means used by the perpetrator in the attack - that is, does the perpetrator use physical force to carry out the act of violence or psychological resources such as verbal or visual attacks? By this definition, beating and shoving someone are examples of physical forms of violence, and so is violence directed at an object: a house or a vehicle, for instance. Degrading talk and threats aimed at a political candidate are examples of psychological forms of violence.

Both physical and psychological violence may or may not have sexual connotations. Accordingly, we take care to integrate potential sexual characteristics into our definition of physical and psychological forms of violence. This is in line with our focus on the means used by the perpetrator, as physical force as well as verbal or visual attacks can be sexual in nature. Sexual violence demands explicit attention, as it is particularly likely to follow gendered patterns and, at the same time, is often stigmatized and underreported (Link and Phelan 2001). One study estimates that sexual violence during the war in Sri Lanka was about 10 times higher than direct reports suggested, because of stigma and the associated underreporting (Traunmüller, Kijewski, and Freitag 2019). While true for sexual violence in general, it is perhaps even more 
pertinent for physical sexual violence when men are the victims (Chakraborty et al. 2018; Hlavka 2016). As a consequence, this study conducts explicit and separate assessments and analyzes of sexual forms of both physical and psychological violence as well as the experiences of both men and women.

It is important to note that the overarching distinction between physical and psychological violence, based on the means used by the perpetrator, says nothing about the consequences of violence or harm done, either to the victim or to the political process (see Bardall, Bjarnegård, and Piscopo 2019). Psychological violence such as threats can have physical consequences for the victim, for instance, by effectively limiting his or her free movement due to fear. Conversely, physical force can have longterm damaging consequences for the psychological well-being of the victim. While these are important aspects to keep in mind, this study is limited to investigating event-based differences in the forms of violence used in attacks against women and men candidates.

\section{GENDER RELATIONS, POSTCONFLICT PATTERNS, AND POLITICS IN SRI LANKA}

Incidents of election violence targeting men and women candidates need to be understood within their specific societal context to properly understand their causes and means of perpetration. The main justification for selecting the case of Sri Lanka is its two features of direct relevance to the literature on gender and violence against political candidates: it is a postconflict country and a new gender quota adopter. Because Sri Lanka is a postconflict country, violence is still highly present in people's memories as well as in remaining practices. In 2016, the country adopted a gender quota in local elections that dramatically increased the number of women candidates.

Our reasoning around underlying assumptions and observable implications favoring either of the two interpretations of violence targeting women in politics described above does not preclude a nuanced analysis. We do not suggest that motivations for using violence necessarily fit neatly into predefined categories or that they are unidimensional. A postconflict setting does not rule out the possibility that there are also instances of gender-based violence as a reaction to the new quota legislation, but neither would the fact that women are 
targeted as women rule out the possibility that some women victims are targeted because they are politicians.

The 25-year-long conflict between the government and the separatist Tamil Tigers (Liberation Tigers of Tamil Ealam, or LTTE) officially ended in 2009. Before the end of the conflict, elections at every level were plagued by regular incidents of physical violence such as shootings, stabbings, beatings, and destruction of property (Uyangoda 2008). Since then, several elections have taken place at different political levels. During these elections, violence in various forms, including lethal violence, has been reported by local (e.g., Centre for Monitoring Election Violence) as well as international (e.g., the European Union) election observation missions. These observation missions have also noted that women's political participation in elections in Sri Lanka is extremely low, both in a global and a regional perspective. Only $5 \%$ of those elected to the national parliament in the 2015 elections were women, and only 2\% of the local councilors were women. The marginalization of women in Sri Lankan parties has manifested, for example, in the exclusion of women from parties' nomination lists and the confinement of women in parliament to traditionally female policy areas such as social service, welfare, and children (Wickramasighe and Kodikara 2012).

The high level of violence in elections in Sri Lanka has been connected to the low number of women in politics. Studies based on interviews point to high levels of physical and psychological violence as commonly mentioned obstacles for women (Gomez and Gomez 2009). The other side of the coin connects male political dominance to the militarization of society and politics in Sri Lanka, during and following the conflict. The militarization of a society can be understood as a process and an ideology that facilitates the institutionalization of militant solutions to different types of conflicts, both formally and informally (see, e.g., de Mel 2007). Militarization and violence have become routinized and a part of established politics.

The high level of election violence in Sri Lanka has been explained by several factors, including the exceptionally high power of the president; the militarization of politics as a result of conflicts between the government and the LTTE and the political party Janatha Vimukthi Peramuna (JVP); multimember constituencies, which require more costly campaigning; increased intraparty competition resulting from the change to a proportional system; and politicians' reliance on criminal gangs and thugs for their political survival (Höglund 2009b; Höglund and Piyarathne 2009). The violence has also had various consequences for 
individuals and their attitudes about and involvement in politics. For instance, it has caused frustration with politics and a disappointment with politicians for failing to protect citizens from violence. There are also testimonies of citizens who refrain from voting because of the violence (Höglund and Piyarathne 2009).

The low number of women in politics is mirrored in women's subordinate positions in many areas of Sri Lankan society. In many areas, women have not received their share of economic development, and this is particularly true in the most conflict-affected areas, in the north and northeastern parts of the country. Even if access to health care and education has improved considerably, for women, this has not translated into political and social power to a very high degree. The representation of women is very low at all political levels, and legislation does not give men and women equal rights regarding marriage and land ownership. Since the end of the conflict, many households are headed by women, and when women enter the labor market, they often do so in insecure working situations, as migrant workers or on plantations. In addition, violence against women is widespread (see, e.g., de Mel 2001; de Mel, Peiris, and Gomez 2013; Gamburd 2011; Sarvananthan 2015; Wickramasighe and Kodikara 2012).

To address women's underrepresentation in Sri Lankan politics, a 25\% electoral gender quota was adopted at the local government level in 2016. The quota applies to both single- and multimember district (or ward) seats and to the proportional representation (PR) seats in the mixed electoral system. This specific design is quite complicated and includes various exceptions that increase the risk that the $25 \%$ target will not be met. However, simply speaking, the law states that at least $10 \%$ of the members assigned a ward (in total, $60 \%$ of the seats) have to be women. In addition, 50\% of those nominated to the PR seats (which are not directly elected) have to be women. The quota was applied for the first time in the 2018 local elections, which is the focus of our analysis.

The amendment of the Local Authorities Elections Act included another important reform: the total number of seats in the local legislative councils was increased to almost twice as many as before the amendment. As a consequence, the quota did not pose as much of a threat to incumbents (primarily men) as it would have without the enlarged number of seats. Yet it did bring an unprecedented number of women into the electoral races (women used to make up less than $10 \%$ of the nominated candidates), thereby significantly changing the dynamics of the elections. In all, 35,000 candidates competed for 8,000 
available seats in Sri Lanka's local governments in the 2018 elections (Colombo Telegraph 2017).

\section{RESEARCH DESIGN}

To analyze women and men candidates' experiences of election violence in the Sri Lanka 2018 local elections, we collected original survey data on 197 candidates (both men and women, winners as well as losers). In addition, we interviewed 21 of these candidates. While the main purpose of the survey was to analyze differences in exposure to election violence between men and women, the interviews mainly served the purpose of getting more detailed information about what the candidates' experiences of violence and intimidation entailed. For this reason, the interviews were conducted only with candidates who had personally experienced election violence in the last local election (for more information about the interviews, see Section 5 of the appendix in the supplementary material online).

Getting access to not only winning but also losing candidates is quite a challenge, not least in a developing context, so a fully randomized and nationally representative sample was not an option. However, we cooperated with the International Foundation for Electoral Systems (IFES) and distributed the survey at local events that it organized around the country to approximate a nationally representative sample. These events were specifically organized for our data collection purposes and took place in June 2018 (i.e., four months after the local elections) across the country: in the north (Jaffna), east (Batticaloa), center (Anuradhapura, Kurunegala, and Nuwara Eliya), west (Colombo), and south (Galle). Participants had access to Singhalese and Tamil facilitators, who had been trained by the authors, while filling out the survey. After the participants had answered the survey, there were group discussions about issues related to electoral violence against political candidates (more information on our data collection can be found in Section 1 of the appendix).

While IFES organized the events, another cooperating partner - the Federation of Sri Lankan Local Government Authorities (FSLGA) was in charge of inviting candidates to the events. The FSLGA contacted local leaders of the major political parties and asked them to bring an equal number of male and female candidates to the workshops. The invitations to the parties mentioned that the topic of the workshop 
was "candidates' experiences of the last local elections." The reason for having a broad invitation was that we did not want a skewed sample that is, we wanted to avoid parties inviting only candidates whom they knew had personally experienced election violence and intimidation.

At a few of the events, we got the impression that many participants knew beforehand that the workshop was going to focus on candidates' experiences of violence in the elections, suggesting that respondents in some districts might have been primed before data were collected. For this reason, we do not use our data to draw conclusions about the prevalence of election violence in the 2018 local elections. However, importantly, we suggest that the risk of priming does not constitute a problem for our research purpose, which is to examine sex differences in election violence and intimidation: we have no reasons to believe, a priori, that any such priming applied more to men than women or vice versa. In addition, we believe that men and women understood the questions equally well. For instance, while collecting the data, there were no indications that the candidates (regardless of sex) were misunderstanding what sorts of acts the survey questions referred to. Furthermore, the interviews provided a source of validation. The interviewees talked about experiences that were clearly related to specific forms of violence. As a consequence, while we caution against using our findings as a measure of the prevalence of election violence, we expect the observed sex differences and similarities in election violence presented in this study to be valid estimates.

The survey asked questions about both physical and psychological violence. Physical violence was assessed not only with a question about whether the candidate experienced bodily violence in relation to the election but also with a question about whether the candidate, or anyone associated with his or her campaign, experienced damage to property in relation to the election. Our measurement of psychological violence included a question about whether the candidate experienced degrading talk or false rumors about himself or herself in relation to the election and another question about whether the candidate was exposed to threats in relation to the election. In addition, we included a separate and specific question about experiences of sexual violence, which could be physical and/or psychological: "Have you experienced any form of intimidation (e.g., degrading talk, false rumors, threats or physical violence) of a sexual nature in relation to the election?" Because of the sensitivity of this topic, we did not ask respondents to differentiate between psychological and 
physical aspects, nor did we ask follow-up questions (e.g., about who perpetrated the violence with sexual connotations). ${ }^{4}$

In the analysis, we present bivariate and multivariate regression models based on the survey. Our main independent variable is candidate sex, and our dependent variable is exposure to election violence - either exposure to any form of violence or to a specific form. The dependent variable is always coded as binary (exposure or no exposure) and outcomes report the share of candidates exposed to violence. For ease of interpretation, the main models use ordinary least squares (OLS) regressions to show the difference between the share of men and women candidates exposed to violence in percentage points (Hellevik 2009). However, as robustness checks, we also ran the models using logistic regression. The results are in line with those of the OLS regressions (see Tables A4-A7 in the appendix). ${ }^{5}$

In the multivariate regressions, we control for candidate-level differences with respect to the ethnicity of the candidate, incumbency, and whether the candidate was elected. ${ }^{6}$ Furthermore, descriptive statistics in Tables $\mathrm{A} 2$ and $\mathrm{A} 3$ in the appendix show that violence exposure differs somewhat across parties and regions. Hence, we introduce fixed effects for these and consequently compare women and men from the same party and the same district (i.e., survey site).

4. The survey has been developed over time, and previous versions were tested in other contexts prior to being fielded in Sri Lanka. Furthermore, several rounds of consultation were held with IFES Sri Lanka to make sure the interpretation of concepts in Sinhala and Tamil were correct and intelligible, and captured relevant aspects of the experiences of election violence in the country.

5. While logistic regression is more appropriate than OLS for binary outcomes, OLS estimates are easier to interpret. Since our full models include fixed effects for districts and parties, presenting marginal effects based on logistic regressions is not a viable option. This would require choosing an "average" party and district, to which there is no logical solution. For a more extensive discussion on using OLS for binary outcomes, see Hellevik (2009).

6. In auxiliary models (available upon request), showing similar findings as those presented in Tables 1 and 2, we also included a measure of the extent to which the candidate's party was dominant in local politics prior to the 2018 election. This is coded at the district level, as the share of local councils or sabhas where the party obtained the largest vote share in the previous local election (in 2011). The 2018 election was significantly affected by a fierce competition between two parties related to the United People's Freedom Alliance (UPFA), which dominated most local councils prior to the election. One of them is the Sri Lanka Freedom Party (SLFP), the UPFA's main constituent party, which is led by Sri Lanka's president, Maithripala Sirisena. The other is the Sri Lanka Podujana Peramuna (SLPP), led by the country's former president and the SLFP's former party leader, Mahinda Rajapakse. Both of these parties are coded as dominant in local politics in the districts where the UPFA enjoyed such a position, since candidates running for both of them enjoyed the advantages of a historically large support base, incumbency, and/or connections to incumbents in the local context. However, because of the small number of observations, there is not enough variation in the data to obtain estimates for all the regional fixed effects when local dominance of the candidate's party is included. 
Finally, we use qualitative interview material to provide richer descriptions of the various forms of violence we measure. Thus, the interviews illustrate what the statistical findings entail in practice by providing examples of the incidents candidates were exposed to and their own interpretations of these events. The interview material also sheds light on some of the limitations of survey research when it comes to adequately capturing sex differences in experiences of different forms of election violence. The qualitative interview material adds nuance to our findings, since they demonstrate gendered patterns within the broader categories of violence investigated.

\section{FINDINGS}

\section{Sex Differences in Overall Exposure to Election Violence}

Starting with sex differences in exposure to at least one form of election violence, broadly defined, Model 1 in Table 1 investigates the bivariate relationship. Compared to men, women were 12 percentage points less likely to be exposed to election violence in general: $77 \%$ of the men respondents compared to $65 \%$ of the women respondents experienced some kind of violence in relation to the election (see also Table Al in the appendix). ${ }^{7}$ The estimate for women's violence exposure relative to men's remains negative, of almost the same size, when we introduce control variables and the fixed effects (Model 2). However, it no longer reaches statistical significance. Taken together, the results tell us that there are no large differences in the extent to which men and women are exposed to election violence but that, if anything, men are more likely victims than women.

Further analyses of the survey data underscore the similarities in exposure to election violence between women and men. Violence was not a rare incident for either sex: a majority of both women and men respondents who reported being exposed to violence experienced it either "several times" or "very often" (see Figure A2 in the appendix). Only $4 \%$ of the men and $10 \%$ of the women exposed to violence reported that it had only happened once. This indicates that violence during the election is, if not an everyday experience, at least widespread

7. Among the surveyed candidates, $71 \%$ experienced some form of violence (see Table $\mathrm{Al}$ in the appendix). For reasons explained in the methods section, it is important to note that this number should not be interpreted as a measure of prevalence of violence against candidates in the local election. 
Table 1. Sex and exposure to election violence, any form of violence

\begin{tabular}{|c|c|c|}
\hline & \multicolumn{2}{|c|}{ Violence } \\
\hline & (1) & (2) \\
\hline Woman & $\begin{array}{c}-0.12 \text { * } \\
(0.06)\end{array}$ & $\begin{array}{l}-0.10 \\
(0.07)\end{array}$ \\
\hline Incumbent & & $\begin{array}{c}0.11 \\
(0.09)\end{array}$ \\
\hline Elected & & $\begin{array}{c}0.02 \\
(0.08)\end{array}$ \\
\hline Tamil & & $\begin{array}{c}0.15 \\
(0.20)\end{array}$ \\
\hline FE for parties: & & \\
\hline SLFP & & $\begin{array}{l}-0.01 \\
(0.17)\end{array}$ \\
\hline SLPP & & $\begin{array}{c}-0.06 \\
(0.18)\end{array}$ \\
\hline UNP & & $\begin{array}{c}-0.17 \\
(0.18)\end{array}$ \\
\hline Other & & $\begin{array}{c}-0.02 \\
(0.13)\end{array}$ \\
\hline FE for districts & & \\
\hline Batticallo & & $\begin{array}{l}-0.15 \\
(0.25)\end{array}$ \\
\hline Colombo & & $\begin{array}{c}-0.17 \\
(0.13)\end{array}$ \\
\hline Galle & & $\begin{array}{c}-0.31^{\text {w. }} \\
(0.13)\end{array}$ \\
\hline Jaffna & & $\begin{array}{l}-0.56^{* * * 4} \\
(0.26)\end{array}$ \\
\hline Kurunegala & & $\begin{array}{l}-0.32^{\text {***k }} \\
(0.12)\end{array}$ \\
\hline Nuwara Eliya & & $\begin{array}{l}-0.16 \\
(0.19)\end{array}$ \\
\hline Constant & 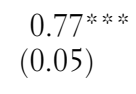 & 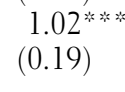 \\
\hline $\begin{array}{l}\text { Observations } \\
R^{2}\end{array}$ & $\begin{array}{l}194 \\
0.02\end{array}$ & $\begin{array}{l}184 \\
0.15\end{array}$ \\
\hline
\end{tabular}

Notes: The constant in Model 1 reports the share of men candidates exposed to at least one form of election violence. The coefficient for woman reports the difference in exposure to election violence among women candidates compared to men in percentage points. Incumbent refers to whether the candidate was a member of the local council during the previous election period, and elected refers to whether the candidate was elected or not in the 2018 election. Tamil reports the difference between Tamil and Sinhalese candidates, with Tamil coded as 1 and Sinhalese as 0 . Fixed effects (FE) for seven districts and five party categories. Standard errors in parentheses.

$* * * * 0.01 ; * * * 0.05 ; * p<.1$. 
and common. Election Day was when men experienced most incidents, followed by the campaign phase, whereas it was the reverse for women (see Figure A3 in the appendix). More women than men reported that they experienced some kind of violence already during the nomination phase. However, in general the sex differences are quite small. Neither do we find large differences in terms of perceived perpetrators, underscoring the relevance of the interpretation that the violence that men and women face is similar to the extent that it comes from their political opponents in the electoral race (see Figure Al in the appendix). The fact that members of other parties are the most common aggressors against women candidates suggests that they are attacked first and foremost as representatives of their party rather than as women - and this dynamic of violence is similar to what men experience. ${ }^{8}$

\section{Sex Differences in Three Forms of Violence}

Next, we analyze the three main forms of violence separately: physical, psychological, and sexual violence, keeping in mind that sexual violence is an overlapping category consisting of both physical and psychological violence. Knowing that sexual violence is often underreported as well as gendered, we take care to give it explicit attention as a third category.

First, we conclude that psychological violence is more common than physical violence - against both men and women. Whereas $69 \%$ of the surveyed candidates reported psychological forms of violence, only $13 \%$ reported physical forms (see Table $\mathrm{Al}$ in the appendix). ${ }^{9}$ It is also important to note that while psychological violence is widespread, it is not universal: $29 \%$ of candidates reported no exposure to degrading talk or threats during their campaign.

Contrary to what most previous research has suggested, Models $1-2$ in Table 2 show that men are not significantly more exposed to physical

8. Among men, $70 \%$ claimed that members of other political parties were among the perpetrators of violent acts. About half of the women respondents claimed that members of other political parties were responsible for the violence they faced. However, women candidates experienced somewhat more violence perpetrated by people in the community. The main pattern is similar when we separate the analysis of perpetrators by violence type: members of other political parties are the most common perpetrators of both psychological and physical violence, against both women and men candidates (see Figure A4 in the appendix).

9. Table Al in the appendix also shows that physical violence directed at the candidate seems to have been quite rare, reported by $5 \%$ in total. Material damage was more common, reported by $10 \%$ of respondents. As for psychological violence, degrading talk was more common than threats. Of the candidates in the sample, $67 \%$ had experienced degrading talk, while $37 \%$ had been threatened. Experiences of violence of a sexual nature, finally, was reported by $11 \%$ of the respondents. 
violence than women. In both the bivariate and multivariate model, there are no significant sex differences. However, the direction of the relationship is the same in both models, indicating that, if anything, women seem to be the victims of slightly more physical violence than men. This is mainly driven by one form of physical violence - property damage - which was experienced by $14 \%$ of the women and $7 \%$ of the men in the sample. The sex differences in bodily violence, though pointing in the same direction, are smaller: $6 \%$ of the women experienced this form of physical violence compared to $4 \%$ of the men (see Table $\mathrm{Al}$ in the appendix).

The interview material mirrors the finding that most reported physical violence was material damage. Damage to property often refers to campaign offices and/or to campaign material (e.g., Interviews 1, 6, 11, 12). A woman candidate, for instance, mentioned that her campaign office was damaged and that all campaign posters were destroyed. Before the incident, she had been successful in getting people to come to her campaign rallies; as a consequence, she suspected that the perpetrator was another candidate (who eventually won the election) or supporters of that candidate (Interview 12). Material damage ranged from campaign posters being tarnished (Interview 1, 6) to arson at the candidate's party office (Interview 11). The interviews indicate that there may be a need to consider a broader range of perpetrators of bodily violence than what is often the case in research on election violence. In at least two cases, it was the husband of the woman candidate who carried out acts of physical violence in reaction to her political activity, either against the candidate herself (Interview 10) or against her party colleagues (Interview 5).

Models 3-4 in Table 2 show the sex differences for a composite measure of the two subcategories of psychological violence: degrading talk and threats. Contrary to suggestions from previous research, men candidates in our sample were more likely to report that they had been victims of psychological violence. The direction and strength of this relationship is fairly constant throughout the models, and regardless of the controls introduced. The relationship is significant in both the bivariate and the multivariate model. As shown in Table Al in the appendix, the relationship appears to be driven by degrading talk. There is a discernible sex difference in the experience of this form of psychological violence, with as many as three-quarters of the men surveyed having experienced degrading talk, while $59 \%$ of the women experienced it. ${ }^{10}$

10. The sex difference is smaller but in the opposite direction when it comes to threats: $35 \%$ of men candidates in the sample and $40 \%$ of the women experienced direct threats. 
Table 2. Sex and exposure to physical, psychological, and sexual violence

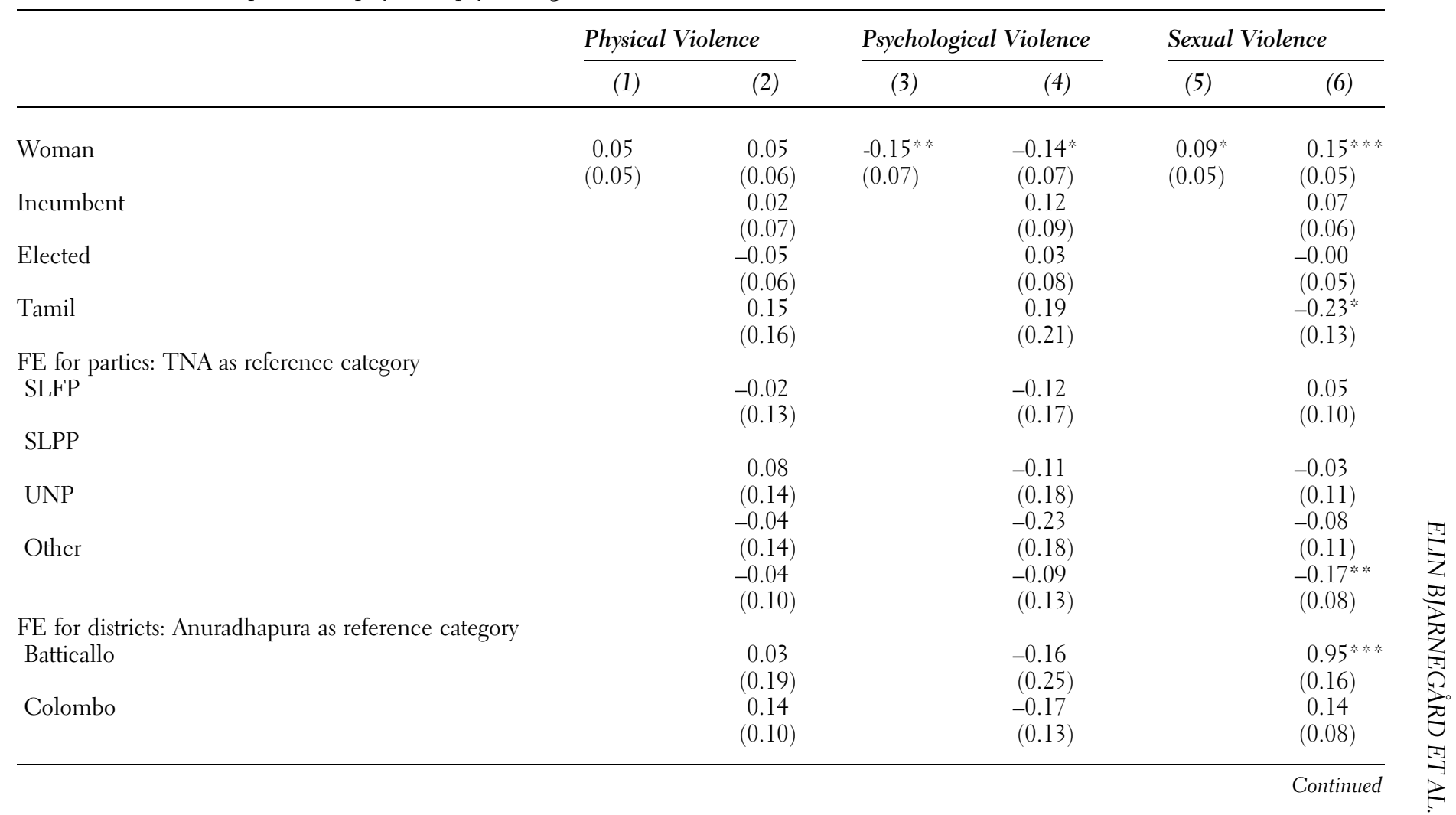


Table 2. Continued

\begin{tabular}{|c|c|c|c|c|c|c|}
\hline & \multicolumn{2}{|c|}{ Physical Violence } & \multicolumn{2}{|c|}{ Psychological Violence } & \multicolumn{2}{|c|}{ Sexual Violence } \\
\hline & (1) & (2) & (3) & (4) & $(5)$ & (6) \\
\hline Galle & & $\begin{array}{c}-0.15 \\
(0.10)\end{array}$ & & $\begin{array}{l}-0.30^{* * *} \\
(0.13)\end{array}$ & & $\begin{array}{c}0.07 \\
(0.08)\end{array}$ \\
\hline Jaffna & & $\begin{array}{c}-0.20 \\
(0.20)\end{array}$ & & $\begin{array}{l}-0.63^{*} \\
(0.26)\end{array}$ & & 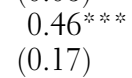 \\
\hline Kurunegala & & $\begin{array}{c}0.02 \\
(0.10)\end{array}$ & & 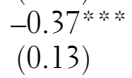 & & $\begin{array}{c}0.10 \\
(0.08)\end{array}$ \\
\hline Nuwara Eliya & & $\begin{array}{c}-0.22 \\
(0.14)\end{array}$ & & $\begin{array}{c}-0.16 \\
(0.19)\end{array}$ & & $\begin{array}{l}0.29 \text { ** } \\
(0.12)\end{array}$ \\
\hline Constant & $\begin{array}{l}0.11^{* * * * * *} \\
(0.03)\end{array}$ & $\begin{array}{c}0.14 \\
(0.15)\end{array}$ & 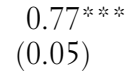 & 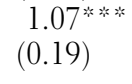 & $\begin{array}{c}0.06^{*} \\
(0.03)\end{array}$ & $\begin{array}{c}-0.10 \\
(0.12)\end{array}$ \\
\hline $\begin{array}{l}\text { Observations } \\
R^{2}\end{array}$ & $\begin{array}{l}191 \\
0.01\end{array}$ & $\begin{array}{l}182 \\
0.13\end{array}$ & $\begin{array}{l}192 \\
0.03\end{array}$ & $\begin{array}{l}183 \\
0.16\end{array}$ & $\begin{array}{r}168 \\
0.02\end{array}$ & $\begin{array}{l}159 \\
0.40\end{array}$ \\
\hline
\end{tabular}

Notes: The constant in Models 1, 3, and 5 reports the share of men candidates exposed to physical election violence. The coefficient for woman reports the difference in exposure to physical election violence among women candidates compared to men in percentage points. Incumbent refers to whether the candidate was a member of the local council during the previous election period, and elected refers to whether the candidate was elected or not in the 2018 election. Tamil reports the difference between Tamil and Sinhalese candidates, with Tamil coded as 1 and Sinhalese as 0 . Fixed effects (FE) for seven districts and five party categories. Standard errors in parentheses.

***** $p<.01 ; * * p<.05 ; * p<.1$. 
To better understand the meaning of degrading talk and threats during election campaigns, the interviews indicate that degrading talk commonly refers to what is described as false accusations, about corruption, vote buying, or disloyalty to the candidate's ethnic group (e.g., Interviews 2 , $6,7,8,10,12,14,15,16)$. For instance, a Tamil man was accused of planning to use the Prevention of Terrorism Act against fellow Tamils, which he felt created an image of him being severely disloyal to his own ethnic group (Interview 7). In addition, several candidates' houses were raided by the police based on accusations of corruption or the illegal selling of alcohol (Interviews 1, 8, 14, 16). Such police raids may tarnish the social standing of the candidate and his or her family in the local community, regardless of whether the accusation is true or not (e.g., Interview 8).

An important nuance brought forth by the interview data concerns the distinction between degrading talk of a political character and degrading talk of a personal character. Although they may overlap in personalized political systems, critical discussions of a political nature are of fundamental democratic value and can also be signs of a vibrant and open political discussion. The interview data suggest that an empirical distinction between political criticism and violations of personal integrity of the political actors may be important (see Bjarnegård 2018). Whereas a candidate's political stance toward certain ethnic groups or his or her engagement in corruption or illegal activities may be of political relevance, the many rumors spread about candidates' personal sexual immorality are decidedly less so (Interviews 5, 7, 9, 10, 16). It was primarily women candidates who recounted rumors about their immorality being spread during their campaigns, so it may well be the case that although men and women alike face degrading talk, its content may be of a different - and gendered - character (see Bardall, Bjarnegård, and Piscopo 2019).

Threats are clearly distinguishable from politically relevant debate as examples of illegitimate violations of personal and electoral integrity. The interviewed candidates had experienced crowds of supporters of competing parties gathering outside their homes, seeking to intimidate them by lighting firecrackers, throwing stones, and speeding the engines on their motorcycles (Interviews 1, 2, 6, 9). Many received direct threats of physical violence, through anonymous phone calls, supporters, or directly in their face (Interviews 1, 3, 5, 6, 10, 18). One man candidate said he received a lot of intimidation from other parties, but that this was expected: “'We will kill you, we will hit you.' That's manageable, that's 
normal. . . . It's a common thing to threaten. It's common language. I was not afraid. (Laughs)" (Interview 18). This quote demonstrates that, at least for some candidates, threats of physical violence are normalized as part of political campaigns in Sri Lanka.

The foregoing discussion about rumors about candidates' morality indicated a need to take a closer look at men's and women's experiences of election violence of a sexual nature. In relation to violence of a sexual nature, it should be reiterated that this is an overlapping category that may include incidents already mentioned as physical or psychological violence. The rationale for constructing a separate category is that there is stigma attached to this form of violence, making it likely to be underreported. We also think that it is likely that rumors of a sexual nature are not taken seriously and that sexual violence that occurs in the home of a candidate may not be recognized as political violence - all contributing to likely underreporting when questions do not specifically mention the sexual nature of the violence. This warrants specific focus on sexual violence. ${ }^{11}$

Models 5-6 in Table 2 show that women candidates reported more experiences of sexual forms of violence than men. While $6 \%$ of the men candidates reported that they had experienced such violence during the campaign, $15 \%$ of the women candidates did (see model 5 in Table 2 or Table $\mathrm{Al}$ in the appendix). The difference remains substantially and statistically significant when we introduce individual-level controls and fixed effects for party and district.

The finding that sexual violence is primarily experienced by women is further indicated by the interviews (Interviews $5,10,12,16$ ). The sexual harassment and rumor spreading that the women candidates described was sometimes perpetrated by their own husbands. One husband was opposed to his wife's political activity and locked her out, threatened people who drove her around, and reported her inappropriate behavior to the police (Interview 5). Another woman candidate's husband made her appear sexually immoral by spreading rumors about her repeated infidelity involving men of another ethnicity, saying that she had HIV and was "loose," a prostitute, and not a good wife. This verbal sexual harassment escalated to severe humiliation and physical assault, including beatings, letting her sleep outside in the pouring rain,

11. The likely underreporting of sexual violence by women and men warrants even stronger caution in relation to interpreting the absolute numbers of victims of this form of violence. Even so, the triangulation of quantitative survey data and qualitative interview data indicates a fairly low level of sexual violence in the sample. 
throwing food and hot water over her, and having sex with another woman in front of her. Throughout this abuse, the husband supported a rival party, and before the election, he even organized a political rally to convey the message that she was a prostitute (Interview 10). However, some of the interviews with men candidates suggested that they had been the targets of similar campaigns, but in these cases, they did not want to elaborate (and were not prompted to do so), which may say something about either increased awareness among women or the additional stigma attached to sexual violations against men. One man mentioned that people had written "terrible things" about him and his wife on Facebook (Interview 9), and another man did not even want to tell us the words that his opponents had used about him, because he "does not say words like that" (Interview 11).

As a final note on the findings, there is one issue that the analysis is not able to fully address, namely, the impact of violence. While we have shown statistically that there are striking similarities in the election violence targeting women and men as candidates in the Sri Lankan election of 2018, there may be important sex differences in relation to the impact. While this was not the focus of the survey, or of the interviews, we did include a question about whether candidates would be willing to run for office again. We see no sex differences in these replies, as most candidates, women and men and winners and losers, reported that they were willing to run for office again. Importantly, experiencing violence, as defined in the survey, does not have a negative impact on the willingness to continue one's political activity. If anything, these appear to be positively correlated (see Table A8 in the appendix). This suggests that violence does not, at least in the short run, depress political ambition.

Other issues pertaining to impact mainly appeared in the interviews, highlighting some potential qualitative differences of being exposed to psychological violence from family members. Two women candidates were banned from their homes by their husbands, as an attempt to dissuade or prevent them from running in the election (Interviews 5, 10). As a comparison, men who reported family members having negative attitudes toward their political involvement explained that their family members supported them in the end and even campaigned for them, even if they were against them running (Interviews 7,11 ). While these examples may be extreme, it seems likely that opposition from within the family has different impacts on men and women candidates and on their campaigns. Moreover, having one's reputation tarnished 
can have more severe consequences for women than for men. Morality, and sexual morality in particular, is a more strictly prescribed norm for women than for men in Sri Lanka, as in most other contexts. This implies that women and men may experience qualitatively different types of violence within the categories outlined in the survey. The violence they experience may also differentially impact men and women, despite the fact that they seem to experience similar frequencies of the same overarching forms of election violence. This possibility deserves further investigation in future research.

\section{CONCLUSIONS}

Election violence can be viewed through a (gendered) strategic lens or interpreted as an everyday political practice. Research on violence against women in politics has leaned toward the former interpretation, framing violent incidents targeting women politicians as strategic attempts to reduce women's political influence. While bringing this interpretation on board, this article incorporates and empirically investigates an alternative possibility: that women are targeted in much the same way as men, in contexts in which violence as a political practice is strikingly common and being a political candidate is associated with high risks. These different interpretations of violence affecting women in politics have previously been theorized, but this article has examined their observable implications.

More specifically, the article has analyzed winning and losing candidates' experiences of election violence during the 2018 local elections in Sri Lanka. Representing one of the first large- $N$ empirical analyses of men and women political candidates' experiences of different forms of election violence (both physical and psychological), the study finds relatively small sex differences. Looking at election violence as a whole (i.e., without differentiating between different forms of violence), men appear to be slightly more exposed to violence than women, although the difference is not statistically significant when control variables are included in the analysis.

When considering the type of violence, we see that this difference is driven by men's higher exposure to psychological violence, mainly degrading talk. The interview material nuances this finding, pointing to the importance of capturing the content of degrading talk. Essentially, a closer analysis of the content of degrading talk is needed to determine 
the extent to which it may be part of a vociferous but politically relevant criticism, or whether it seeks to illegitimately affect the election by attacking the personal integrity of political actors. More fine-grained analyses of degrading talk may well unveil sex differences in its content that are obscured by the rather broad category employed here.

With respect to physical violence, there are no discernable or significant differences between men and women. The lack of clear sex differences go against findings in previous research on political violence suggesting that men are more likely victims of physical forms of violence while women are more likely victims of psychological violence. Our analysis is unable to explain why sex differences are small in Sri Lanka but seemingly greater elsewhere (cf. Bardall 2011); however, our findings underscore that context matters and that we cannot universally assume that physical violence mainly targets men and psychological violence mainly targets women.

When we qualify the analysis to account for when and how often violence occurs, we conclude that violent acts are not rare incidents in this election, but rather something that occurred several times during the election process. This leads us to interpret the violence as a routinized, "everyday" aspect of election campaigns. Most violence seems to take place after the nomination phase and before the election result has been announced, that is, during the campaign and on Election Day. Our analysis of perpetrators indicates that the most common perpetrators by far - are perceived to be members of rivalling parties. Again, overall, the sex differences in these analyses are small.

These findings suggest that in postconflict Sri Lanka, violence is used by candidates and their supporters to get an electoral advantage over their political opponents. In other words, even though victims of election violence express that they perceive it as highly unjust and reprehensible, it is largely seen as part of the electoral game. Although we lack data over time, we suggest that the inclusion of more women in electoral races did not substantially change these dynamics. Again, the overall sex differences are quite small. Our results indicate that in contexts marked by election violence, we should acknowledge the possibility that women may be targeted in similar ways, and to a similar extent, as men.

However, in one important respect, women's presence in electoral campaigns, as candidates, appears to be associated with an enlarged, and gendered, "toolbox" of violence also in Sri Lanka. Women are substantially more often victims of sexual violence, that is, of intimidation (e.g., degrading talk, false rumors, threats, or physical violence) of a sexual nature in relation to the election. Sexualized forms 
of violence seem to be largely reserved for women in political contexts all around the world, and postconflict Sri Lanka is no exception. Thus, even where violence and intimidation appear to be widespread and expected as a part of electoral politics, certain forms of violence almost exclusively target women. This analysis alone cannot fully discern whether these sexualized forms of violence are used against women politicians because they are seen as more efficient means of attacking politicians that happen to be women, or if their gendered and sexualized nature reflects an opposition to women politicians as such. The fact that our analysis was able to single out sexual violence as a form of physical and psychological violence that is almost uniquely experienced by women in Sri Lanka, however, demonstrates the importance of focusing specifically on sexual violence and of comparing men and women. An important future extension of this analysis is to get a deeper understanding of both the similarities and differences in men's and women's exposure to specific forms of election violence as well as to conduct this research in other political contexts, keeping interpretations of violence as strategically targeting women as well as violence as a political practice open.

There are at least three additional extensions of this study that deserve scholarly attention. First, future research should address potential sex differences in the consequences of election violence. While our study investigates gender in the motive and form of violence, it has less to say about its potentially gendered impact (cf. Bardall, Bjarnegård, and Piscopo 2019). To reiterate, with the data at hand, we cannot preclude the possibility that the same form of attack has a different impact on men and women candidates. Though we did not find a negative impact of violence on candidates' willingness to run for office again, it is possible that widespread degrading talk against candidates can depress ambition among prospective candidates. As newcomers in politics, and due to gendered norms on respectability, such an impact may apply even more to women than men.

Second, empirical examinations should analyze sex differences over time. This study provides a snapshot view of a sample of candidates in one election only. The fact that men and women did not experience significant differences in violence exposure in these local elections, when women first entered politics in greater numbers, does not rule out that gendered motivations for violence against political actors may arise if and when women reach more powerful positions and truly challenge male hegemony over politics. 
Third, future analyses should include intersectional approaches of gendered election violence by investigating variation in exposure to violence within subgroups of women and men. Such analyses would require the analysis of a larger number of candidates than those we have been able to survey in this initial comparison of men's and women's exposure to election violence.

To conclude, the main lessons from this analysis are important. They suggest that violence as a political practice should be acknowledged as a possible interpretation of electoral violence targeting women. At the same time, the fact that sexual violence seems to be almost reserved for women also demonstrates the need for gender-sensitive analyses of election violence.

Elin Bjarnegård is Associate Professor of Political Science at Uppsala University: elin.bjarnegard@statsvet.uu.se; Sandra Håkansson is a PhD candidate in Political Science at Uppsala University: sandra.hakansson@ statsvet.uu.se; Pär Zetterberg is Associate Professor of Political Science at Uppsala University: par.zetterberg@statsvet.uu.se

\section{SUPPLEMENTARY MATERIAL}

To view supplementary material for this article, please visit https:/doi.org/ $10.1017 / \mathrm{S} 1743923 \mathrm{X} 20000471$

\section{REFERENCES}

Albaine, Laura. 2015. "Obstáculos y desafíos de la paridad de género. Violencia política, sistema electoral e interculturalidad." Íconos: Revista de Ciencias Sociales 19 (52): 145-62.

Asociación de Concejalas de Bolivia (ACOBOL). 2012. "Acoso y Violencia Política En Razón de Género Afectan El Trabajo Político y Gestión Pública de Las Mujeres." https://www.tse.go.cr/revista/art/13/eugenia_rojas.pdf (accessed September 13, 2020).

Ballington, Julie. 2018. "Turning the Tide on Violence against Women in Politics: How Are We Measuring Up?” Politics \& Gender 14 (4): 695-701.

Bardall, Gabrielle. 2011. "Breaking the Mold: Understanding Gender and Electoral Violence.” White paper, International Foundation for Electoral Systems, December. https://www.ifes.org/sites/default/files/gender_and_electoral_violence_2011.pdf (accessed September 13, 2020).

Bardall, Gabrielle. 2017. "The Role of Information and Communication Technologies in Facilitating and Resisting Gendered Forms of Political Violence." In Gender, Technology and Violence, eds. Marie Segrave and Laura Vitis. New York: Routledge, 100-117 
Bardall, Gabrielle, Elin Bjarnegård, and Jennifer Piscopo. 2019. "How Is Political Violence Gendered? Disentangling Motives, Forms, and Impacts." Political Studies. Published online December 3. https://doi.org/10.1177/0032321719881812.

Bekoe, Dorine A., ed. 2012. Voting in Fear: Electoral Violence in Sub-Saharan Africa. Washington, DC: United States Institute of Peace Press.

Biroli, Flávia. 2016. "Political Violence against Women in Brazil: Expressions and Definitions." Revista Direito e Práxis 7 (15): 557-89.

Bjarnegård, Elin. 2013. Gender, Informal Institutions and Political Recruitment: Explaining Male Dominance in Parliamentary Representation. Basingstoke: Palgrave Macmillan.

Bjarnegård, Elin. 2018. "Making Gender Visible in Election Violence: Strategies for Data Collection." Politics E Gender 14 (4): 690-95.

Bjarnegård, Elin. forthcoming. The Continuum of Election Violence. Gendered Candidate Experiences in the Maldives. International Political Science Review.

Bjarnegård, Elin, and Pär Zetterberg. 2016. "Political Parties and Gender Quota Implementation: The Role of Bureaucratized Candidate Selection Procedures." Comparative Politics 48 (3): 393-417.

Cerva Cerna, Daniela. 2014. "Participación política y violencia de género en México." Revista Mexicana de Ciencias Políticas y Sociales 59 (222): 117-40.

Chakraborty, Tanika, Anirban Mukherjee, Swapnika Reddy Rachapalli, and Rarai Saha. 2018. "Stigma of Sexual Violence and Women's Decision to Work." World Development 103: 226-38.

Collignon, Sofia, and Wolfgang Rüdig. 2020. "Harassment and Intimidation of Parliamentary Candidates in the United Kingdom.” Political Quarterly 91 (2): 422-29.

Colombo Telegraph. 2017. "Do Local Government Elections Really Matter?” December 27. https://www.colombotelegraph.com/index.php/do-local-government-electionsreally-matter/ (accessed September 13, 2020).

de Mel, Neloufer. 2001. Women and the Nation's Narrative: Gender and Nationalism in Twentieth Century Sri Lanka. Boston: Rowman \& Littlefield.

de Mel, Neloufer. 2007. Militarizing Sri Lanka: Popular Culture, Memory and Narrative in the Armed Conflict. Los Angeles: Sage Publications.

de Mel, Neloufer, Pradeep Peiris, and Shyamala Gomez. 2013. "Broadening Gender: Why Masculinities Matter: Attitudes, Practices and Gender-Based Violence in Four Districts in Sri Lanka." Care International, April. https:/www.care.org.au/wp-content/uploads/ 2014/12/Sri-Lanka-Broadening-Gender_Why-Masculinities-Matter.pdf (accessed September 21, 2020).

Fischer, Jeff. 2002. "Electoral Conflict and Violence: A Strategy for Study and Prevention." White paper, International Foundation for Electoral Systems, February 5. https://www. ifes.org/sites/default/files/econflictpaper.pdf (accessed September 13, 2020).

Gamburd, M. R. 2011. “Female Labor Migration from Sri Lanka to the Middle East.” In The Sri Lanka Reader, ed. John Clifford Holt. Durham, NC: Duke University Press, 687-94.

Gomez, Mario, and Shyamala Gomez. 2009. "The Reluctance of Women to Enter Politics." In Excluding Women: The Struggle for Women's Political Participation in Sri Lanka, eds. Morina Perera and Rasika Chandrasekera. Colombo, Sri Lanka: Social Scientists' Association.

Håkansson, Sandra. Forthcoming. "Do Women Pay a Higher Price for Power? Gender Bias in Political Violence in Sweden." Journal of Politics.

Hellevik, Ottar. 2009. "Linear versus Logistic Regression When the Dependent Variable Is a Dichotomy." Quality and Quantity 43: 59-74.

Herrick, Rebekah, Sue Thomas, Lori Franklin, Marcia L. Godwin, Eveline Gnabasik, and Jean Reith Schroedel. 2019. "Physical Violence and Psychological Abuse against 
Female and Male Mayors in the United States." Politics, Groups, and Identities. Published online June 16. https://doi.org/10.1080/21565503.2019.1629321.

Hlavka, Heather R. 2016. "Speaking of Stigma and the Silence of Shame: Young Men and Sexual Victimization." Politics \& Gender 20 (4): 482-505.

Höglund, Kristine, 2009a. "Electoral Violence in Conflict-Ridden Societies: Concepts, Causes and Consequences." Terrorism and Political Violence 21 (3): 412-27.

Höglund, Kristine. 2009b. "Elections and Violence in Sri Lanka: Understanding Variation across Three Parliamentary Elections." In The Democratization Project: Opportunities and Challenges, eds. Ashok Swain, Ramses Amer, and Joakim Öjendal. London: Anthem Press, 135-52.

Höglund, Kristine, and Anton Piyarathne. 2009. "Paying the Price for Patronage: Electoral Violence in Sri Lankao." Commonwealth 6 Comparative Politics 47 (3): 287-307.

Hughes, Melanie, Pamela Paxton, and Mona Lena Krook. 2017. "Gender Quotas for Legislatures and Corporate Boards." Annual Review of Sociology 43: 331-52.

Kahn, Kim Fridkin. 1996. The Political Consequences of Being a Woman: How Stereotypes Influence the Conduct and Consequences of Political Campaigns. New York: Columbia University Press.

Kelly, Liz. 1988. Surviving Sexual Violence. Cambridge: Polity Press.

Kenny, Meryl. 2013. Gender and Political Recruitment. Theorizing Institutional Change. Basingstoke: Palgrave Macmillan.

Kittilson, Miki Caul, and Kim Fridkin. 2008. "Gender, Candidate Portrayals and Election Campaigns: A Comparative Perspective.” Politics \& Gender 4 (3): 371-92.

Krook, Mona Lena. 2015. "Empowerment versus Backlash: Gender Quotas and Critical Mass Theory." Politics, Groups, and Identities 3 (1): 184-88.

Krook, Mona Lena. 2016. "Contesting Gender Quotas: Dynamics of Resistance." Politics, Groups, and Identities 4 (2): 268-83.

Krook, Mona Lena. 2017. "Violence against Women in Politics." Journal of Democracy 28 (1): 74-88.

Krook, Mona Lena. 2018. "Violence against Women in Politics: A Rising Global Trend." Politics E Gender 14 (4): 673-75.

Krook, Mona Lena. 2020. Violence against Women in Politics. New York: Oxford University Press.

Krook, Mona Lena, and Juliana Restrepo Sanín. 2016a. "Gender and Political Violence in Latin America. Concepts, Debates and Solutions.” Política y Gobierno 23 (1): 127-62.

Krook, Mona Lena, and Juliana Restrepo Sanín. 2016b. "Violence against Women in Politics. A Defense of the Concept." Politica y Gobierno 23 (2): 459-90.

Krook, Mona Lena, and Juliana Restrepo Sanín. 2020. “The Cost of Doing Politics? Analyzing Violence and Harassment against Female Politicians." Perspectives of Politics 18 (3): 740-55.

Link, Bruce G., and Jo C. Phelan. 2001. "Conceptualizing Stigma." Annual Review of Sociology 27: 363-85.

Muriaas, Ragnhild, Vibeke Wang and Rainbow Murray, eds. 2019. Gendered Electoral Financing. Money, Power and Representation in Comparative Perspective. New York: Routledge.

National Democratic Institute (NDI). 2018. "Not the Cost: Stopping Violence against Women in Politics." Submission to the United Nations Special Rapporteur on Violence Against Women. https://www.ndi.org/sites/default/files/NDI\%20Submission. pdf (accessed September 21, 2020).

Norris, Pippa. 2013. "The New Research Agenda Studying Electoral Integrity." Electoral Studies 32 (4): 563-75. 
Norris, Pippa, and Joni Lovenduski. 1995. Political Recruitment. Gender, Race and Class in the British Parliament. Cambridge: Cambridge University Press.

Piscopo, Jennifer M. 2016. "State Capacity, Criminal Justice, and Political Rights. Rethinking Violence against Women in Politics." Politica y Gobierno 23 (2): 437-58.

Rasmussen, Jacob. 2018. "Parasitic Politics: Violence, Deception and Change in Kenya's Electoral Politics." In Violence in African Elections: Between Democracy and Big Man Politics, eds. Mimmi Söderberg Kovacs and Jesper Bjarnesen. London: Zed Books, 176-96.

Sarvananthan, Muttukrishna. 2015. "Impediments to Women in Post-Civil War Economic Growth in Sri Lanka." South Asian Journal of Human Resources Management 2 (1): $12-36$.

Söderberg Kovacs, Mimmi. 2018. "Introduction: The Everyday Politics of Electoral Violence in Africa." In Violence in African Elections: Between Democracy and Big Man Politics, eds. Mimmi Söderberg Kovacs and Jesper Bjarnesen. London: Zed Books, 1-25.

Staniland, Paul. 2014. "Violence and Democracy." Comparative Politics 47 (1): 99-118.

Traunmüller, Richard, Sara Kijewski, and Markus Freitag. 2019. "The Silent Victims of Sexual Violence during War: Evidence from a List Experiment in Sri Lanka." Journal of Conflict Resolution 63 (9): 2015-42.

Uyangoda, Jayadeva, ed. 2008. Matters of Violence: Reflections on Social and Political Violence in Sri Lanka. Colombo, Sri Lanka: Social Scientists' Association.

Wickramasighe, Maithree, and Chulani Kodikara. 2012. "Representation in Politics: Women and Gender in the Sri Lankan Republic." In The Sri Lankan Republic at 40: Reflections on Constitutional History, Theory and Practice- An Edited Collection of Essays, ed. Assanga Welikala. Colombo, Sri Lanka: Centre for Policy Alternatives, 721-820. 